\title{
Clinico-Biochemical Abnormalities in Hospitalized Neonates with or without Seizure
}

\author{
Shah Muhammad Masuduzzaman ${ }^{* 1}$, Md Nazrul Islam², Md Abid Hossain Mollah², \\ Mohammad Azizul Hoque ${ }^{4}$, Md Anwar Hossain ${ }^{5}$, Md Saiful Islam ${ }^{6}$
}

\section{Abstract}

Introduction: To determine the clinical types and etiological factors and to assess the biochemical abnormalities in neonates with seizure. Materials and Methods: This was a Cross-sectional, comparative hospital based study. Ninety neonates, age up to 28 days of both sexes were evaluated for clinical types, etiological factors and biochemical abnormalities with seizure and compared with those having no seizures. The variables were analyzed using student t- test. All the data was processed and analyzed by computer software SPSS version 15.0. Level of significance was considered as $p$ value less than 0.05. Results: Most of the neonates having seizures (72\%) within 3 days of life. The seizures were common in male babies (62\%). 35\% of the mother of baby with seizure gave history of prolonged labour. HIE was diagnosed $56.67 \%$ neonates with seizure whereas infection were found in 25\% cases with seizure. Among the seizure subtypes, subtle seizures were 58\% followed by clonic seizures $30 \%$. Significant biochemical changes we found in 43.34\% of neonates with seizures. Hypocalcemia (46\%) was most common followed by hypoglycemia(38\%). Conclusion: Hypoxic ischemic encephalopathy was the commonest cause of neonatal seizure followed by neonatal infections including meningitis and sepsis.. Biochemical abnormalities are more common in neonates with seizure than neonates free from seizure. Among the biochemical abnormalities hypocalcaemia and hypoglycemia occurs most commonly followed by hyponatraemia and hypomagnesaemia.

Keywords: Neonate, Seizure, Biochemical abnormality.

Number of Tables: 03; Number of Figures: 02; Number of References: 24; Number of Correspondence: 04.

*1. Corresponding Author:

Dr. Shah Muhammad Masuduzzaman MBBS, MD

Assistant Professor

Sheikh Hasina Medical College, Tangail.

E-mail: drmasudzaman@gmail.com

Mobile: +88 01711-181939

2. Professor Dr. Md Nazrul Islam, MBBS, FCPS Professor \& Head, Department of Paediatrics Community Based Medical College Hospital Mymensingh.

3. Professor Dr. Md Abid Hossain Mollah MBBS, FCPS, Dip Med Ed, FACP, FRCP

Professor \& Head

Department of Neonatology and Paediatrics

BIRDEM General Hospital, Dhaka.

4. Professor Dr. Mohammad Azizul Hoque MBBS, FCPS, MHP Ed, Ex-Professor \& Head Department of Paediatrics Mymensingh Medical College Hospital Mymensingh.

5. Professor Dr. Md Anwar Hossain, MBBS, MD Ex Principal, Mymensingh Medical College \& Head Department of Neonatology Mymensingh Medical College Hospital Mymensingh.

6. Dr. Md Saiful Islam, MBBS, DCH, FCPS

Assistant Resistrar

Department of Paediatrics

250 Beded General Hospital, Tangail.

\section{Introduction:}

Neonatal seizures are common and may be the first manifestation of neurological dysfunction after a variety of insults ${ }^{1}$. Neonatal seizures are clinically significant because very few are idiopathic ${ }^{1,2}$. Moderate to severe acute hypoxic ischemic encephalopathy (HIE) accounts for approximately two third of all cases of neonatal seizures ${ }^{3}$. Biochemical disturbances occur frequently in neonatal seizures either as an underlying cause or as an associated abnormality ${ }^{4,5,6}$. Among the biochemical abnormalities hypocalcemia and hypoglycemia were most common showed in different studies. Hypoglycemia is common among neonates whose mothers have diabetes, large for gestational age, having HIE or other stresses ${ }^{7}$. Early onset (first 72 hours) hypocalcemia usually associated with preterm LBW, IUGR, asphyxia, infant of diabetic mother where as late onset hypocalcemia is seen in child fed evaporated cow's milk \& other improper formulas ${ }^{3,8}$. About half of neonates with seizures secondary to hypocalcemia, also have hypomagnesemia and should be considered if seizures continue after given therapy ${ }^{7,9}$. Prognosis of neonatal seizures however is related to pathogenesis i.e. prolong or recurrent hypoglycemia permanently affect the $\mathrm{CNS}^{7}$. Thus early recognition and treatment of biochemical disturbances is essential for optimal management and satisfactory long term outcome ${ }^{1,2}$. The present study is designed to assess the biochemical abnormalities associated with neonatal seizure and to compare the findings with those of neonates having no seizures.

\section{Materials \& Methods:}

The present study was a cross sectional, comparative study conducted in the department of pediatrics, Mymensingh Medical College Hospital, Mymensingh, Bangladesh from 1st July 2008 to 30th June 2009. Total 90 neonates within 28 days of life were included in the 
study. Among them 60 were with seizures and rest 30 were without seizures. Both study group and reference group were taken according to inclusion criteria and selected randomly. Seizures were diagnosed and classified by author himself or by authorized person. The neonatal seizures were classified according to Volpe's classification. Hypoglycemia were defined as blood sugar $<40 \mathrm{mg} / \mathrm{dl}$, and hypocalcaemia when total serum calcium was $<7.0 \mathrm{mg} / \mathrm{dl}$. Age, sex, etiological factors and biochemical parameters were recorded in a predesigned data sheet. The data was analyzed by using SPSS version 15.0 .

\section{Results:}

Total 90 neonates who were admitted into neonatal unit in $\mathrm{MMCH}$ included in this study. Among them 60 having convulsion and rest are without convulsion. Out of 90 neonates $54(60 \%)$ were male and $36(40 \%)$ were female. $37(61.67 \%)$ of the neonates with seizure were male. On the other hand $17(56.66 \%)$ males having no seizure among control group. Most of the seizures about 43 $(71.66 \%)$ cases occurring in our study within first three days of life. In the present study 32 babies had seizure in the range of 1-15 minutes. 27 babies had seizures less than 1 minute of duration and one baby had seizure persisting more than 15 minutes. Among the mothers of neonates with seizure, 34(56.6\%) suffered from different types of problems during pregnancy or labour. Twenty one (56.6\%) having history of prolong labour and $5(8.3 \%)$ having PROM. Majority about $42(70 \%)$ in neonates with seizure and $18(60 \%)$ in neonates without seizure had normal vaginal delivery and caesarian section were $16(26.6 \%)$ and $12(40 \%)$ respectively. Thirty five (58\%) neonates with seizure were born in home. Most of the neonates with seizure 58(96.67\%) and without seizure 27 $(90 \%)$ under study were born within normal gestational period. Maximum patient under this study were born at term about $91 \%$. About $16(26.66 \%)$ of the neonates were fed with foods other than colostrums in neonates with seizure. Neonates were subsequently fed with breast milk in 41 cases in neonates with seizure. Hypoxic ischemic encephalopathy (HIE) was the commonest diagnosis found in $34(56.67 \%)$ neonates with seizure group and other causes are septicemia, meningitis intracranial hemorrhage and low birth weight. No cause could be identified in $4(6.67 \%)$ cases of neonates with seizure, out of which $3(5 \%)$ suspected clinically due to primary metabolic disorder. Subtle types of seizure were noticed in $35(58.33 \%)$ cases and subsequently focal or multifocal clonic were $18(30 \%)$ and $7(11.67 \%)$ patients had tonic type of seizures. One of them was generalized tonic convulsion. There was no myoclonic type of seizure diagnosed. 26(43.33\%) patients had eye manifestation and $16(26.67 \%)$ patients had mouth deviation. The biochemical parameters done in the present study were the blood glucose, serum calcium, serum sodium, serum magnesium, serum potassium and serum inorganic phosphate level and to see if any significant biochemical changes in different types of seizure occurring due to different causes and it was compared with that in non-seizure neonates.

The mean serum sodium $(134.8 \pm 4.3 \mathrm{meq} / \mathrm{L})$ was found to be much lower in the neonates with seizure than the neonates without seizure $(139.74 \pm 3.5 \mathrm{meq} / \mathrm{L})$. The mean blood glucose level in the neonates with seizure was 2.72 $\pm 0.91 \mathrm{~m} \mathrm{~mol} / \mathrm{L}$ which was also much lower than the other group where it was $4.18 \pm 0.96 \mathrm{mmol} / \mathrm{L}$. The neonates with seizure also had lower mean serum calcium level $7.25 \pm 0.4 \mathrm{mg} / \mathrm{dl}$ which was $8.51 \pm 0.72 \mathrm{mg} / \mathrm{dl}$ in case of neonates without seizure (Table III).

Table-I: Values expressed as number and percentages. The total no. of significant biochemical changes are more due to multiple response i.e. multiple biochemical changes in a single case.

\section{Table-I: Types of seizure with biochemical changes.}

\begin{tabular}{|c|c|c|c|c|c|c|c|c|c|}
\hline \multirow{2}{*}{$\begin{array}{l}\text { Seizures } \\
\text { type }\end{array}$} & \multirow{2}{*}{$\begin{array}{l}\text { Total } \\
\text { no } \\
\text { of } \\
\text { cases }\end{array}$} & \multirow[b]{2}{*}{$\begin{array}{l}\text { Signi } \\
\text { ficant } \\
\text { bioche } \\
\text { mical } \\
\text { change }\end{array}$} & \multirow{2}{*}{$\begin{array}{l}\text { Hypo } \\
\text { glyce } \\
\text { mia }\end{array}$} & \multicolumn{2}{|c|}{ Serum $\mathrm{Na}$} & \multirow{2}{*}{$\begin{array}{l}\text { Hypo } \\
\text { calcae } \\
\text { mia }\end{array}$} & \multirow{2}{*}{$\begin{array}{l}\text { Hypo } \\
\text { magne } \\
\text { semia }\end{array}$} & \multirow{2}{*}{$\begin{array}{l}\text { Hypo } \\
\text { kalaem } \\
\text { ia }\end{array}$} & \multirow[b]{2}{*}{$\begin{array}{l}\text { Hype } \\
\text { phos } \\
\text { phate } \\
\text { mia }\end{array}$} \\
\hline & & & & Hypo & Hyper & & & & \\
\hline Subtle & 35 & $\begin{array}{c}16 \\
(45.71 \%)\end{array}$ & 5 & 2 & 0 & 6 & 2 & 1 & 0 \\
\hline Clonic & 18 & $\begin{array}{c}10 \\
(55.55 \%)\end{array}$ & 4 & 0 & 1 & 4 & 1 & 0 & 0 \\
\hline Tonic & 7 & $4(57.14 \%)$ & 1 & 1 & 0 & 2 & 0 & 0 & 0 \\
\hline $\begin{array}{l}\text { Myo } \\
\text { clonic }\end{array}$ & 0 & 0 & 0 & 0 & 0 & 0 & 0 & 0 & 0 \\
\hline Total & 60 & $\begin{array}{c}26 \\
(43.33 \%)\end{array}$ & $\begin{array}{c}10 \\
(38.4 \%)\end{array}$ & $\begin{array}{c}3 \\
(11.5 \%)\end{array}$ & $\begin{array}{c}1 \\
(3.8 \%)\end{array}$ & $\begin{array}{c}12 \\
(46.1 \%)\end{array}$ & $\begin{array}{c}3 \\
(11.5 \%)\end{array}$ & $\begin{array}{c}1 \\
(3.8 \%)\end{array}$ & 0 \\
\hline
\end{tabular}

Fig 1: Hypoxic ischemic encephalopathy (HIE) was the commonest diagnosis was found in $56.67 \%$ neonates with seizure group. Infection in the form of septicemia and meningitis were found in $25 \%$ cases with seizure.

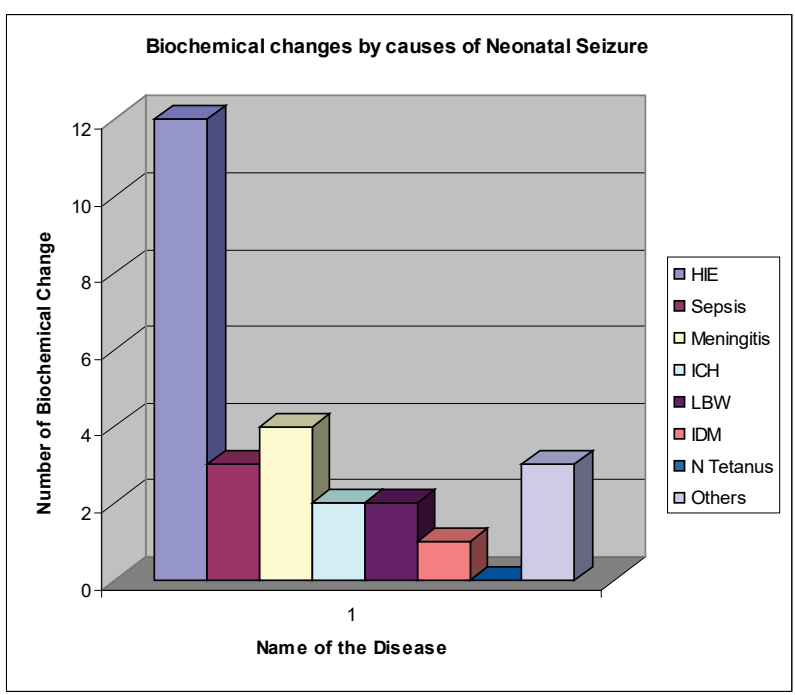

Figure-1: Clinical diagnosis of the neonates with seizur.

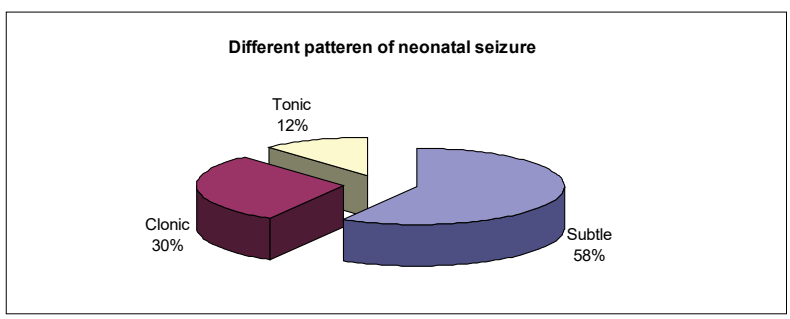

Figure-2: Types of seizure among Study group $(n=60)$. 
Table II. shows hypocalcemia and hypoglycemia were more common in neonates with seizure where as hypoglycemia and hyponatraemia were found in neonates without seizure.

Table-II: Distribution of seizure and non seizure neonates with biochemical changes.

\begin{tabular}{lcc}
\hline $\begin{array}{l}\text { Biochemical } \\
\text { parameters }\end{array}$ & $\begin{array}{c}\text { Neonates with } \\
\text { Seizures }(\mathbf{n}=60)\end{array}$ & $\begin{array}{c}\text { Neonates without } \\
\text { Seizures }(\mathbf{n}=30)\end{array}$ \\
\hline Hypoglycemia & $10(16.67 \%)$ & $1(3.34 \%)$ \\
Hypocalcaemia & $12(20 \%)$ & 0 \\
Hypomagnesaemia & $3(5 \%)$ & 0 \\
Hyponatraemia & $3(5 \%)$ & $1(3.34 \%)$ \\
Hypernatraemia & $1(1.67 \%)$ & 0 \\
Hypokalaemia & $1(1.67 \%)$ & 0 \\
Hyperphosphatemia & 0 & 0 \\
\hline
\end{tabular}

Table III: Statistical T-test was done to see if there is any statistically significant difference in the biochemical levels of the neonates with seizure and no seizure. Statistically significant difference $(p<0.001)$ was found in cases of Blood glucose, Serum calcium, Serum sodium and Serum magnesium level between the two groups.

Table-III: T-test: Neonates with seizure and no seizure by biochemical changes.

\begin{tabular}{|c|c|c|c|c|c|c|}
\hline Biochemical parameters & Seizure & Number & Mean & SD & T-value & P-value \\
\hline \multirow{2}{*}{$\begin{array}{l}\text { Blood Glucose } \\
(\mathrm{m} \mathrm{mol} / \mathrm{L})\end{array}$} & Yes & 60 & 2.72 & .91 & \multirow[t]{2}{*}{7.02} & \multirow[t]{2}{*}{$<.001$} \\
\hline & No & 30 & 4.18 & .96 & & \\
\hline \multirow{2}{*}{$\begin{array}{l}\text { Serum Sodium } \\
(\mathrm{meq} / \mathrm{L})\end{array}$} & Yes & 60 & 134.8 & 4.3 & \multirow[t]{2}{*}{5.3} & \multirow[t]{2}{*}{$<.001$} \\
\hline & No & 30 & 139.74 & 3.5 & & \\
\hline \multirow{2}{*}{$\begin{array}{l}\text { Serum Calcium } \\
(\mathrm{mg} / \mathrm{dl})\end{array}$} & Yes & 60 & 7.25 & .40 & \multirow[t]{2}{*}{10.4} & \multirow[t]{2}{*}{$<.001$} \\
\hline & No & 30 & 8.51 & .72 & & \\
\hline \multirow{2}{*}{$\begin{array}{l}\text { Serum Potassium } \\
(\mathrm{meq} / \mathrm{L})\end{array}$} & Yes & 60 & 4.28 & .68 & \multirow[t]{2}{*}{.79} & \multirow[t]{2}{*}{$>.05$} \\
\hline & No & 30 & 4.4 & .66 & & \\
\hline \multirow{2}{*}{$\begin{array}{l}\text { Serum Magnesium } \\
(\mathrm{mg} / \mathrm{dl})\end{array}$} & Yes & 60 & 1.91 & .35 & \multirow[t]{2}{*}{3.5} & \multirow[t]{2}{*}{$<.001$} \\
\hline & No & 30 & 2.35 & .29 & & \\
\hline \multirow{2}{*}{$\begin{array}{l}\text { Serum Phosphate } \\
(\mathrm{mmol} / \mathrm{L})\end{array}$} & Yes & 60 & 2.1 & .33 & \multirow[t]{2}{*}{.88} & \multirow[t]{2}{*}{$>.05$} \\
\hline & No & 30 & 2.03 & .40 & & \\
\hline
\end{tabular}

\section{Discussion:}

Neonatal seizure is an acute emergency which is responsible for very high morbidity and mortality ${ }^{10,11}$. Neonatal seizure observed more in male patient $(61.67 \%)$ than female $(38.33 \%)$ in this study which is consistent with study done by Taksande AM et $\mathrm{al}^{10}$ showed $66.4 \%$ male and $33.6 \%$ in female newborn. Shah et $\mathrm{al}^{11}$ also found male predominant in neonatal seizure. The most common seizure type in term and preterm babies is the subtle seizure $^{12,13}$. In this study, majority of the patients $(58.33 \%)$ showed subtle type of seizure whereas clonic and tonic seizures were $30 \%$ and $11.67 \%$ respectively. Ross et al ${ }^{14}$ showed $40.6 \%$ subtle, $35.59 \%$ clonic, $8.9 \%$ generalized tonic and $27.78 \%$ myoclonic type of seizures. Soni A et al ${ }^{15}$ reported $25 \%$ subtle and $37.5 \%$ tonic seizures and Taksande AM et $\mathrm{al}^{10}$ showed $31.1 \%$ subtle and $46.7 \%$ clonic seizures in term babies whereas $48.4 \%$ had subtle and $27.2 \%$ had clonic seizures in preterm babies and tonic seizures observed in $19.4 \%$ and $24.2 \%$ in term and preterm babies respectively. Shah et $\mathrm{al}^{11}$ reported $42.2 \%$ subtle, $44.4 \%$ clonic, $11.1 \%$ tonic and $2.2 \%$ myoclonic seizures in a observational study conducted in Nepal.

Coen RW et $\mathrm{al}^{16}$ found $81 \%$ of babies had early onset seizures $(<72 \mathrm{hrs})$. Ross AL et $\mathrm{al}^{14}$ and Taksande AM et $\mathrm{al}^{10}$ also found early onset seizures in $50.33 \%$ and $85.45 \%$ babies respectively whereas in this study we found $71.66 \%$ neonates had seizures within 72 hrs. Brown $\mathrm{JK}$ et $\mathrm{al}^{17}$ observed $43 \%$ neonates had seizures in the first 4 days of life while Ronen GM et $\mathrm{al}^{18}$ reported $83 \%$ seizures in the first week of the life.

The etiology of neonatal seizure is not disease specific and may be due to a combination of abnormalities ${ }^{4}$. The most common cause of seizure encountered in this study was birth asphyxia, occurred in $34(56.67 \%)$ cases. Sood et al, ${ }^{4}$ Kumar et $\mathrm{al},{ }^{5}$ and Shah et $\mathrm{al}^{11}$ reported birth asphyxia as etiology of seizure was $45.71 \%, 48.27 \%$ and $44 \%$ cases respectively which are comparable with the result of present study. Similar observation seen by Mizrahi where HIE as the cause of convulsion in $46 \%$ cases $^{19}$. Taksande $\mathrm{AM}$ et $\mathrm{al}^{10}$ reported $42.7 \%$ and Brown et $\mathrm{al}^{17}$ showed $65 \%$ cases of neonates of perinatal asphyxia experienced with seizure. Eriksson $\mathrm{M}$ et al, ${ }^{20}$ Painter MJ et al ${ }^{21}$ and Holden $\mathrm{KR}^{22}$ et al also showed similar results.

Sepsis in neonate is often associated with meningitis and is a cause of significant morbidity and mortality ${ }^{12}$. A study conducted by Legido A et $\mathrm{al}^{23}$ reported 5\% septicemia and $12.25 \%$ meningitis. Ross et $\mathrm{al}^{14}$ showed $9.5 \%$ babies had septicemia. Shah et $\mathrm{al}^{11}$ and Taksande AM et al ${ }^{10}$ both of the study reported about $20 \%$ cases suffered from infection; sepsis and meningitis combined. These results are concordance with our study where sepsis were diagnosed in $13.33 \%$ cases and meningitis in $11.67 \%$ cases of neonates with seizure. Preterm babies are more vulnerable to intraventricular hemorrhage either spontaneously or as a result of Perinatal asphyxia ${ }^{13}$. Taksande AM et al ${ }^{10}$ showed $1.29 \%$ term neonate and $18.18 \%$ preterm neonate had IVH whereas Ross et $\mathrm{al}^{14}$ and Scher MS et $\mathrm{al}^{24}$ also reported higher incidence of IVH in preterm babies which are comparable with present study where we found out of three neonates $(5 \%)$ having IVH which were diagnosed clinically and one of them were preterm.

The incidence of primary metabolic cause of convulsion is about $10 \%{ }^{12}$. In this study, $4(6.67 \%)$ cases no other cause of seizure could be detected. Out of them $3(5 \%)$ were clinically suspected as primary metabolic disorder. One of them was hypoglycemic and other two cases showed significant hypocalcaemia. Hypomagnesaemia was associated with one of the hypocalcemic baby. Kumar et al shown primary metabolic disorder accounted $25.7 \%$ causes of seizure $^{5}$. This is in contrast to report from western countries where improvements in infant feeding practices have made this category an uncommon cause of seizures ${ }^{8}$. In a study by Cockburn et al it was found that $55 \%$ of neonatal seizures were due to primary disturbance of mineral metabolism ${ }^{6}$.

Hypocalcaemia was the most common biochemical abnormalities among $12(46.15 \%)$ neonates in this study (Table I) 
similar to the study done by Sood et $\mathrm{al}^{4}$ about $48.27 \%$ and Kumar et $\mathrm{al}^{5}$ about $31.8 \%$ cases. Hypoglycemia was the second most common biochemical abnormalities found in $38.46 \%$ cases which similar to Sood et $\mathrm{al}^{4}$ and Kumar et $\mathrm{al}^{5}$ where values were $48.27 \%$ and $50 \%$ respectively. Shah et $\mathrm{al}^{11}$ reported $22 \%$ whereas Taksande et $\mathrm{al}^{10}$ experienced only $8.1 \%$ of hypoglycemia in neonatal seizures. Three $(11.53 \%)$ neonates with seizure present with hyponatraemia and $1(3.84 \%)$ with hypernatraemia, 1(3.84\%) with hypokalaemia and $3(11.53 \%)$ with hypomagnesaemia which is comparable with study done by Sood et $\mathrm{al}^{4}$ and Kumar et $a l^{5}$ where reported $17.24 \%$ and $45.45 \%$ cases of hyponatraemia respectively. Hypernatraemia and hypokalaemia we found was associated with HIE. Two baby of hypomagnesaemia were associated perinatal asphyxia and one was suspected primary metabolic disorder. Two cases were associated with hypocalcaemia. Kumar et al found hypomagnesaemia in $9 \%$ case of neonatal seizures ${ }^{5}$ which is consistent with our study.

Biochemical changes we found $6.67 \%$ cases of neonates without seizures and $43.33 \%$ neonates with seizures. Among these non-seizure cases, one $(3.3 \%)$ was hyponatraemic diagnosed as a case of birth asphyxia and another one was hypoglycemic diagnosed as neonatal sepsis. The biochemical changes found in the non-seizure neonates may be attributed to the disease conditions with which the neonates were admitted to the hospital. The mean of all the biochemical parameters except serum phosphate were found to be higher (within normal range) in the non-seizure cases. The difference in the mean value of glucose, calcium, magnesium and sodium between the two groups was found to be statistically significant $(\mathrm{p}<0.001)$.

In this study, though individual variation in respect of race, geography and socioeconomic condition are present even then most of the study findings are consistent with that done in abroad.

\section{Conclusion:}

Perinatal asphyxia leading to Hypoxic ischemic encephalopathy was the commonest cause of neonatal seizure followed by neonatal infections including meningitis and sepsis. Most seizures occurred within first 72 hours of postnatal age. Meningitis mostly occurs after first week of life. Subtle seizure was the commonest type of seizure that can easily missed, as it is very mild. Biochemical abnormalities are more common in neonates with seizure than neonates free from seizure. Among the biochemical abnormalities hypocalcaemia and hypoglycemia occurs most commonly followed by hyponatraemia and hypomagnesaemia.

\section{Conflict of Interest: None.}

\section{Acknowledgement:}

Thanks and all praise to Almighty Allah, for giving me enough energy to complete this article. Special thanks to my mentor Prof. Md Nazrul Islam, Head of the department of pediatrics CBMCH as the guide of the thesis was conducted at the department of pediatrics, Mymensing Medical College Hospital. Also thankful to all other co-authors and all the stuffs of department of pediatrics, $\mathrm{MMCH}$.

\section{References:}

1. Evans D, Levene M. Neonatal seizures. Arch Dis Child Fetal Neonatal Ed. 1998; 78: F70-F75.

https://doi.org/10.1136/fn.78.1.F70

PMid:9536846 PMCid:PMC1720746

2. Gomlla T L. Neonatal seizures. In: Neonatology: Management, Procedures, On-call problems, Diseases, and Drugs. 5th edn, McGraw Hill, New York; 2004: 496-501. 3. Fenichel GM. Paroxismal disorder of newborn. In: Clinical Pediatric Neurology. 4th Ed. W B Saunders Company Philadelphia; 2001:1-5.

4. Sood A, Grover N and Sharma R. Biochemical abnormalities in Neonatal seizures. Indian J Pediatrics. 2003; 70(3): 221-224.

https://doi.org/10.1007/BF02725588

PMid:12785293

5. Kumar A, Gupta V, Kacchawaha J.S. and Singla P.N Biochemical Abnormalities in Neonatal Seizures. Indian Pediatrics. 1995; 32: 424-428.

6. Cockburn F, Brown JK, Belton NR, Forfar JO. Neonatal convulsions associated with primary disturbance of calcium, phosphorus, and magnesium metabolism. Arch Dis Child. 1973; 48: 99-108.

https://doi.org/10.1136/adc.48.2.99

PMid:4690525 PMCid:PMC1648180

7. Neonatal seizure disorders. Neurologic disorders in children. [Internet] Merck manual professional. Available from: http://www.merck.com/mmpe/sec 19/ch283html

8. Calciolari G, Perlman JM, Volpe JJ. Seizures in the intensive care unit of the 1980s. Types, etiologies, timing. Clin Pediatr. 1988; 27: 119-123.

https://doi.org/10.1177/000992288802700301

PMid:3342595

9. Kalra V. Neonatal seizure. In: Practical Pediatric Neurology. 1st ed., New Delhi: Arya Publications; 2002: 25-30.

10. Taksande AM, Vilhekar K, Jain M, Lakra M. Clinico-

biochemical profile of neonatal seizures.Pediatric oncall [serial online] 2005. Available from: http://www.Pediatric on call.com/For doctor/medical_original_articles/Neonatal_seizures org.

11. Shah GS, Sing MK, Budhathoki S, Kalakheti BK, Baral DD. Clinico-biochemical profile of Neonatal Seizure. J Nepal Pediatr Soc. 2008; 28(1): 7-9.

https://doi.org/10.3126/jnps.v28i1.1398

12. Rennie J M. Neonatal neurology. In: McIntosh N, Helms PJ, Smyth RL, editors. Forfar \& Arneils Textbook of Pediatrics. 6th ed. Edinburgh, UK; 2003: 309-24.

13. Kuban KCK and Filiano J. Neonatal seizures. In: Cloherty JP, Stark AR, Ed. Manual of neonatal care.4th ed. Philadelphia; 1997: 493-505.

14. Ross AL, Lombroso C. Neonatal seizures state: A study of clinical, pathology and electrographic features in 137 full term babies with long term follow up. Pediatrics. 1970; 45: 404-425. 
15. Soni A, Sabarawal AK, Amita K. Clinical profile of seizures in neonatal intensive case unit. In: Manual abstract of XXIII, Annual convention of national neonatology forum. 2003; P 43: 109-110.

16. Coen RW, Mc Cutchen CB, Warma D. Continuous monitoring of electroencephalogram following perinatal asphyxia. J. Pediatr. 1982; 100: 628-630.

https://doi.org/10.1016/S0022-3476(82)80773-7

17. Brown JK, Cockburn F and Forfur JO. Clinical and chemical correlate in convulsion of new born. Lancet. 1992; 1: 135-138.

https://doi.org/10.1016/S0140-6736(72)90694-0

18. Ronen GM, Penny S and Andrew W. The epidemiology of clinical neonatal seizures in new foundland- A population based study. J Pediatrics. 1999; 134: 71-75.

https://doi.org/10.1016/S0022-3476(99)70374-4

19. Mizrahi EM. Neonatal Seizures: Problems in diagnosis and classification. Epilepsia 1987; 28: 546-55.

https://doi.org/10.1111/j.1528-1157.1987.tb05757.x

PMid:3113930
20. Eriksson M, Zetterstrom R. Neonatal convulsion. Incidence and causes in Stockholm area. Acta Pediatr Scand. 1979; 68: 807-811.

https://doi.org/10.1111/j.1651-2227.1979.tb08216.x

PMid:539404

21. Painter MJ, Bergmann I and Cumrine P. Neonatal Seizures. Pediatr Clin North Am. 1986; 33(1): 91-105.

https://doi.org/10.1016/S0031-3955(16)34971-9

22. Holden KR, Mellitus D and Freeman JM. Neonatal Seizures I. Correlation of Prenatal and Perinatal events with outcome. Pediatrics. 1982; 70: 165-176.

23. Legido A, Clancy RR, Berman PH. Neurologic outcome after electroencephalographically proven neonatal seizures. Pediatrics. 1991; 88: 583-596.

24. Scher MS, Aso K, Beggarly ME, Hamid MY, Steppe DA and Painter MJ. Electrographic seizures in preterm and full-term neonates: clinical correlates, associated brain lesions, and risk for neurologic sequelae. Pediatrics. 1993; 91: 128-134. 